\title{
Correction to: Cholestyramine treatment in two dogs with presumptive bile acid diarrhoea: a case report
}

\author{
L. Toresson ${ }^{1,2^{*}}$, J. M. Steiner ${ }^{3}$ and J. S. Suchodolski ${ }^{3}$
}

\section{Correction to: Canine Med Genet 8, 1 (2021) \\ https://doi.org/10.1186/s40575-021-00099-x}

Following publication of the original article [1], the authors identified an error that $\mathrm{mg} / \mathrm{kg}$ should be $\mathrm{g} / \mathrm{kg}$ in the Discussion section.

The correct sentences should read:

One recent study reported that a cholestyramine dose of $0.7 \mathrm{~g} / \mathrm{kg} \mathrm{q} 24 \mathrm{~h}$ administered for 14 days to 12 healthy Beagle dogs appeared to be clinically safe [32]. No side effects or weight loss were noted. The faecal dry matter content increased with cholestyramine treatment, but the number of bowel movements did not increase and faecal scores were still in the normal range. Macro- nutrient apparent total tract digestibility decreased after cholestyramine treatment, but remained in the normal range. It should be noted that the dose used in these studies was 7 times higher than the doses used in this case report $(0.058 \mathrm{~g} / \mathrm{kg} \mathrm{q} 12 \mathrm{~h}$ and $0.059 \mathrm{~g} / \mathrm{kg} \mathrm{q} 12 \mathrm{~h}$, respectively).

The original article [1] has been corrected.

\section{Author details}

${ }^{1}$ Department of Equine and Small Animal Medicine, Faculty of Veterinary Medicine, Helsinki University, Agnes Sjobergin katu 2, 00014 Helsinki, Finland. ${ }^{2}$ Evidensia Specialist Animal Hospital, Bergavagen 3, 25466 Helsingborg, Sweden. ${ }^{3}$ Gastrointestinal Laboratory, Department of Small Animal Clinical Sciences, College of Veterinary Medicine and Biomedical Sciences, Texas A\&M University, 4474 TAMU, College Station, TX 77843-4474, USA.

The original article can be found online at https://doi.org/10.1186/s40575021-00099-x.

* Correspondence: linda.toresson@evidensia.se

'Department of Equine and Small Animal Medicine, Faculty of Veterinary Medicine, Helsinki University, Agnes Sjobergin katu 2, 00014 Helsinki, Finland

${ }^{2}$ Evidensia Specialist Animal Hospital, Bergavagen 3, 25466 Helsingborg, Sweden

Full list of author information is available at the end of the article
Published online: 20 May 2021

Reference

1. Toresson, et al. Cholestyramine treatment in two dogs with presumptive bile acid diarrhoea: a case report. Canine Med Genet. 2021;8:1. https://doi. org/10.1186/s40575-021-00099-X.

(c) The Author(s). 2021 Open Access This article is licensed under a Creative Commons Attribution 4.0 International License, which permits use, sharing, adaptation, distribution and reproduction in any medium or format, as long as you give appropriate credit to the original author(s) and the source, provide a link to the Creative Commons licence, and indicate if changes were made. The images or other third party material in this article are included in the article's Creative Commons licence, unless indicated otherwise in a credit line to the material. If material is not included in the article's Creative Commons licence and your intended use is not permitted by statutory regulation or exceeds the permitted use, you will need to obtain permission directly from the copyright holder. To view a copy of this licence, visit http://creativecommons.org/licenses/by/4.0/ The Creative Commons Public Domain Dedication waiver (http://creativecommons.org/publicdomain/zero/1.0/) applies to the data made available in this article, unless otherwise stated in a credit line to the data. 